\title{
Language Learning Strategies Used by ESL Students of a Chinese Secondary School in Improving Speaking Skills
}

Chee Kooi Lian, Devanageswari Kathiyaiah, Farah Hani, Priya Sivananda, Vinotheni Chanderan, Harwati Hashim

To Link this Article: http://dx.doi.org/10.6007/IJARBSS/v11-i6/10036

DOI:10.6007/IJARBSS/v11-i6/10036

Received: 12 April 2021, Revised: 17 May 2021, Accepted: 30 May 2021

Published Online: 14 June 2021

In-Text Citation: (Lian et al., 2021)

To Cite this Article: Lian, C. K., Kathiyaiah, D., Hani, F., Sivananda, P., Chanderan, V., \& Hashim, H. (2021). Language Learning Strategies Used by ESL Students of a Chinese Secondary School in Improving Speaking Skills. International Journal of Academic Research in Business and Social Sciences, 11(6), 703-716.

\section{Copyright: (c) 2021 The Author(s)}

Published by Human Resource Management Academic Research Society (www.hrmars.com) This article is published under the Creative Commons Attribution (CC BY 4.0) license. Anyone may reproduce, distribute, translate and create derivative works of this article (for both commercial and non-commercial purposes), subject to full attribution to the original publication and authors. The full terms of this license may be seen at: http://creativecommons.org/licences/by/4.0/legalcode

Vol. 11, No. 6, 2021, Pg. 703- 716

Full Terms \& Conditions of access and use can be found at http://hrmars.com/index.php/pages/detail/publication-ethics 


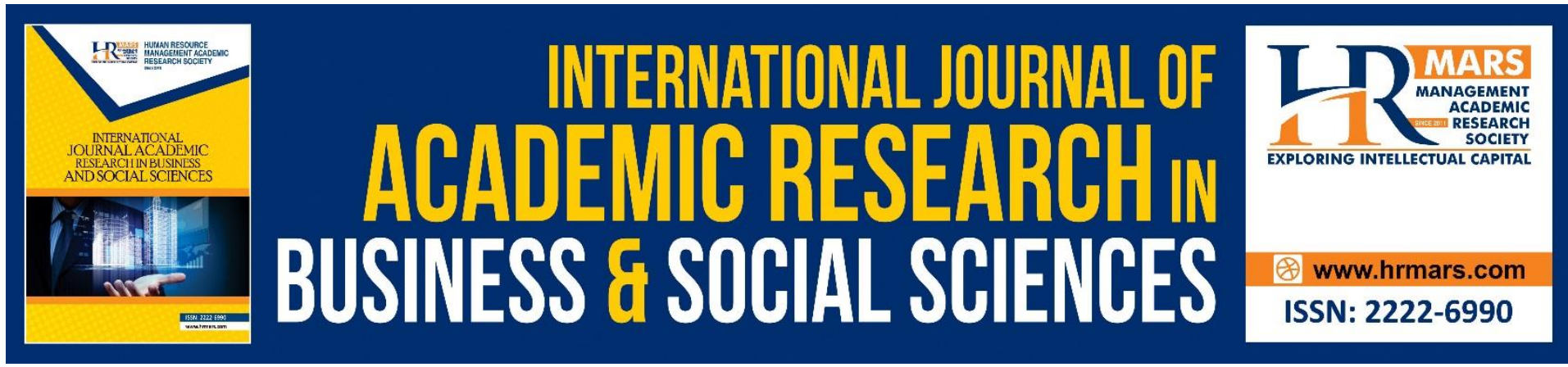

\title{
Language Learning Strategies Used by ESL Students of a Chinese Secondary School in Improving Speaking Skills
}

\author{
Chee Kooi Lian, Devanageswari Kathiyaiah, Farah Hani, Priya \\ Sivananda, Vinotheni Chanderan, Harwati Hashim. \\ Faculty of Education, Universiti Kebangsaan Malaysia, Bangi, Selangor, Malaysia.
}

\begin{abstract}
In this globalization era, English has progressively become the medium in every aspect of communication, both in local and international surroundings. Hence, there is a request for speakers who can communicate in English productively in every country. Speaking is one of the most fundamental skills in English language education. A lot has been discussed relating to the good language learners, but not much is investigated about the strategies used in a Chinese school in order to further improve and acquire their second language learning skills. Besides that, students differ in proficiency, hence a suitable language learning strategy needs to be identified to enhance their speaking skills. Thus, this paper aims to identify language learning strategies and also to discover the direct or indirect strategies used by ESL students of a Chinese Secondary school in improving speaking skills. This study employed a quantitative design where a questionnaire was used in collecting the data. The survey was conducted among 50 Senior 2 learners in a particular Chinese school. A purposive sampling technique was used to select the students for this study. The results of the study have indicated that the metacognitive approach is the most often utilized language learning strategy among Independent Chinese School students in enhancing speaking skills. Furthermore, the findings and implications in this study may be beneficial to some ESL educators in exploring the effectiveness of utilizing suitable language learning strategies in enhancing speaking skills in the future.
\end{abstract}

Keywords: Language Learning Strategy (LLS), ESL Learners, Speaking Skills, Chinese Independent Secondary School (CISS)

\section{Introduction}

With the era of globalization, English has grown to be the main language that has been practiced locally and globally in diverse sets of environments. The English language has also increasingly become the language of choice in any sphere of communication as it has become the medium that allows the learners to be able to interact with other people from other countries. In Malaysia, English is considered a second language where it is frequently used in the education setting for daily interaction and other purposes. The English language has been taught at different levels by educators. Hashim (2018) stated that learners from different 
levels starting from the primary, secondary, and even tertiary levels of education have been urged to learn the English language as it has become one of the skills that need to be acquired. Thirusanku (2014) added that learning the English language has given various opportunities to learners to use the language when interacting with others in different kinds of settings including education and working purposes. Other than that, learners can fully acquire the language by mastering the various skills of the language. The skills of learning the language are divided into four skills which are reading, writing, speaking, and listening. Various researches have stated that learners must be able to acquire these four skills as it operates together in allowing learners to understand the language learned. Therefore, most of the researchers have acknowledged that speaking skill is viewed as the most crucial skill that needs to be mastered by learners when learning a new language.

Furthermore, Boonkit (2010) also emphasized that English is an international language and it is the most important skill required for communication among the four macro English skills. An individual needs to be able to dominate speaking skills as it carries more weight in learning a foreign language, and the ability to carry on a conversation in that language is measured as success. The skill of speaking shows that the learner knows how to use that language, but communicating in an additional language is not an easy task that could be grasped by learners. It requires courage and preparation to communicate well in the new language. Boonkit (2010) stated that "speaking has five components namely: grammar, vocabulary, comprehension, fluency, and pronunciation". The students have to be cautious of these aspects before they speak and convey their ideas. Besides that, using correct pronunciation needs to be used as it might be a challenge for listeners to understand them. Moreover, adequate vocabulary needs to be developed and the ability to organize their sentences needs to be acquired for the learners to understand them. In reality, the proficiency of the secondary students in a Chinese school in speaking English is an issue to be worried about. The UEC curriculum states that students are required to be able to convey their ideas via interpersonal communication in a daily life context which means students need to be able to express their thoughts effectively in a situation. The biggest concern is many Chinese secondary school students are unable to convey their message and thoughts effectively. They surely face difficulties that hinder them to be competent at speaking; such as lack of vocabulary, poor or unusual pronunciation, and poor grammar (Heriansyah, 2012). Even though many language methods have been included in the school's lesson, the results are still not satisfying.

Although it is seen as the most essential skill by many of the researchers nevertheless it may be defying for other people. Having the ability to converse well in English gives confidence to the learner and be more motivated during a conversation. In regards to that, the learner's language learning strategy has played a primary role in enabling the learners to fulfill their education goals. Language learning strategies or LLS was defined by Oxford (1990) as the steps that are taken by learners in discovering the most suitable strategy that suits themselves in obtaining the knowledge. Kashefian-Naeeini (2010) added that learners must determine the best language learning strategy that could make the education process more easy-going, efficient, and more delightful for learners. Many researchers agreed that successful language learners depend on their choices of language learning strategy. Nevertheless, each individual may have chosen a different language learning strategy. Besides that, Sykes (2015) has mentioned that the phrase 'individual differences' is known as the preferences of an individual in determining the most workable strategy to master the speaking skill may differ depending on their encouragement and level of comprehension. 
Each of the individuals may practice several language learning strategies through the process of learning the language. The individuals believed that the strategies preferred are the most reliable way in allowing them to entirely understand the language and apply it to socialize with other people. Therefore, a suitable language learning strategy needs to be incorporated to enhance students' speaking skills.

\section{Research Questions}

1.What are the learning strategies used by the Senior 2 ESL students of a Chinese Secondary school in improving speaking skills?

2. Do the Senior 2 ESL students in Chinese Secondary school use direct or indirect strategies to improve speaking skills?

\section{Literature Review \\ Language Learning Strategy}

A language is a standardized mode of communication that humans use. It consists of speech, expressions, and writing. The majority of languages use a glyph-based scheme to describe both the original sound or word and its context (Fromki, Rodman \& Hyams, 2018). Additionally, language acquisition is a continuous practice that begins at birth and continues throughout one's life. Students develop language skills by expressing their thoughts, feelings, and experiences, forming relationships with family and friends, and attempting to make sense of their environment. Any learning process requires that a system or methodology be adapted in order to achieve the primary purpose of learning. Two critical elements of the method are "what" to use for studying and "how" to use it. Additionally, the Learning Strategies square relates to students' activities and operations aimed at enhancing their mechanisms for gathering and storing knowledge, recalling, and effectively completing assignments or achieving objectives with the use of the appropriate technique. In other words, they examine their attitudes and activities (the strategies) which are heavily influenced by their own learning designs (Nisbet \& Shucksmith, 2017). Thus, according to Pawlak (2019), the phrase "Language Learning Strategies (LLS)" applies to the processes and behaviors that language learners consciously use in order to improve their comprehension and usage of a language. In summary, language acquisition approaches are an integral part of learning methods and they play such a critical role in the language learning phase.

Language acquisition strategies have received considerable interest since the early 1970s, owing to the crucial role they perform in language learning. Numerous researchers view language acquisition methods in a variety of ways. Language Learning Strategies are described differently by various scholars, and this has been decided upon by Winarsih, Salam, and Riyanti (2021). Ali, Zaman, and Khan (2018) assert that there are several modes of learning that exist both within and outside the classroom. The learners are granted autonomy and are prepared to work independently and develop their own system of language learning. On the other side, Language Learning Strategies are described as the proven actions, attitudes, movements, or methods that learners employ to assist them in internalizing, preserving, extracting, and utilizing the second language (Oxford, 1990). Additionally, Oxford (1990) discovered that exceptional language learners use a variety of learning styles that correspond to their own learning designs. According to Hashim (2018), learners often believe that implementing language learning techniques is beneficial to their language mastery. Learners will understand and follow the proper procedures for using and using the learning 
methods, and will be prepared to adapt and incorporate the methods within their own lifestyle (Rubaai, Hashim, \& Yunus, 2019).

To begin, Rubin and Naiman (1975) sought to describe the tactics utilized by effective language learners when studying a second language in the 1970s, which sparked early research into language learning strategies. Adan \& Hashim (2021) assert that LLSs have experienced developmental phases. The classification started in the 1970s, coinciding with the explosion of research in the area of LLSs. Lee (2010), as quoted by Adan \& Hashim (2021), explains that at least five scholars have suggested a distinct classification system for LLSs. Any time an analysis is done, changes are made to the classification and typology.

According to Rubin, students use a number of approaches to supplement their education (1975). Meanwhile, according to Shi (2017); Naiman and Frohlich (1975) developed a collection of useful dialect learners' methodologies, namely that they learn to think in the dialect and discuss feasible dialect securing angles. Oxford (1990) improved classification with the use of direct and indirect methods. Three main strategies and three indirect strategies equal six strategies, as outlined in the table below:

\begin{tabular}{|c|c|c|}
\hline Type & Primary Strategies & Secondary Strategies \\
\hline \multirow[t]{3}{*}{ - $\begin{array}{l}\text { Direct } \\
\text { Strategies }\end{array}$} & $\begin{array}{l}\text { A. Memory } \\
\text { Strategies }\end{array}$ & $\begin{array}{l}\text { - Creatingmental Linkages } \\
\text { - Applying images and sounds } \\
\text { - Reviewing Well } \\
\text { - Employing Action }\end{array}$ \\
\hline & $\begin{array}{l}\text { B. Cognitive } \\
\text { Strategies }\end{array}$ & $\begin{array}{l}\text { - Practicing } \\
\text { - Receiving and sendingmessages } \\
\text { - Analyzing and reasoring } \\
\text { - Creating structure for input and output }\end{array}$ \\
\hline & $\begin{array}{l}\text { C. Compensation } \\
\text { Strategies }\end{array}$ & $\begin{array}{l}\text { - Guessing intelligently } \\
\text { - Overcoming limitation in speaking and } \\
\text { writing }\end{array}$ \\
\hline \multirow[t]{3}{*}{ - $\begin{array}{l}\text { Indirect } \\
\text { Strategies }\end{array}$} & $\begin{array}{l}\text { A. Metacogritive } \\
\text { Strategies }\end{array}$ & $\begin{array}{l}\text { - Centeringyour leaming } \\
\text { - Arranging and planringyour leaming } \\
\text { - Evaluatingyour leaming }\end{array}$ \\
\hline & $\begin{array}{l}\text { B. Affective } \\
\text { Strategies }\end{array}$ & $\begin{array}{l}\text { - Encouragingyourself } \\
\text { - Reducingyour anxiety } \\
\text { - Takingyour emotional temperature }\end{array}$ \\
\hline & C. Social Strategies & $\begin{array}{l}\text { - Cooperating with others } \\
\text { - Empathizing with others } \\
\text { - Asking Questions }\end{array}$ \\
\hline
\end{tabular}

Figure 1: Oxford's Language Learning Strategy Systems (Oxford, 1990)

Based on the table above, Oxford (1996) grouped Language Learning Strategies (LLS) into six categories: memory, cognitive compensation, metacognitive, affective, and emotional. According to Oxford (1996), learners who often use the memory method prefer to learn by analogy and grouping in order to retain information. Adding on, memorization makes a difference in students to store in memory imperative data accumulated from learning. When the data is required for utilization within the future, these strategies help the 
students to urge back the information. On the other side, cognitive learners enjoy recording their acquired skills, learning, and reviewing it. This technique is used to assist students in correctly controlling the desired dialect or task by using all of their methods. Meanwhile, learners who choose the reward option usually begin by speculating and rephrasing in order to familiarize themselves with the new facts. It is used for students to substitute for knowledge that has been missed inside the target dialect due to the lack of a lexicon. This strategy enables students to communicate and type in the target dialect even though their lexicon is reduced.

On the other hand, meta cognitive users love activities such as self-monitoring, concentration, and preparation for a mission or project since these tasks enable them to remember, understand, and synthesize previously acquired knowledge. This makes a difference to the learners to control their own learning. At the same time, students will moreover be able to arrange what their learning methodologies ought to be and alter them on the off chance that they are not appropriate. The affective approach is synonymous with self-encouragement, since it entails learners controlling their feelings and behaviors optimally. This technique includes an effective impact on dialect learning since it permits the understudies to oversee their feelings. Finally, learners that use the social technique love bonding with their peers and engaging with others in a dynamic way. It is a methodology that locks in understudies to look for openings to be uncovered to an environment where practice is conceivable. Adding on to that, it is a vital technique as dialect learning always involves other individuals; it may be a frame of social conduct.

In short, according to many past researchers, Oxford's LLS classification scheme is one of the most comprehensive classification systems to date. This inventory has been heavily used in the collection of data for various studies conducted around the globe. Oxford's LLSs definition is the most well-known and commonly adopted since it is comprehensive, and she develops a very helpful survey called the Strategy Inventory Language Learning (SILL) that is critical for teachers and educators in assessing and defining students' favorite LLSs.

\section{ESL Learners}

Malaysia is an astonishingly diverse country, home to a wide variety of races and ethnic groups. Each race and ethnic group have its own mother tongue, and the national dialect that is Bahasa Melayu. This raises another problem: the rank of English in Malaysia. It is all up to the gentleman. For certain people, English can turn out to be a second or third language. For instance, a Chinese student can converse in Mandarin as his native tongue, Bahasa Melayu as his second language, and English as his third. Despite this, teaching a mother tongue is not as challenging as learning a second or foreign language, as the mother tongue's essence is purer and easier than different types of language. As a consequence, learners will be able to master a second language more effectively with the use of LLSs.

Earlier study has demonstrated that LLSs have a noteworthy influence on assisting learners in enhancing their second language learning. For example, Bayuong, Hashim, and Yunos (2019) indicated that the appropriate methods and techniques will assist learners in the language learning phase. Numerous studies have shown that it has an outstanding effect on moving learners from inadequate to successful learners. It will be even more advantageous in Malaysia, where students would research several languages. 
According to Zaw (2019), literally, language learning is a challenging procedure for learners since it is thought to be sociocognitive, meaning that dialect can be learned through the method of social interaction. It is additionally crucial for the language learners to think of the lesson as a space where everybody has to get to the same learning and to the ideal condition for supporting mental interest. In order to induce the objective of supporting the learners with listening, speaking, reading, writing, and understanding English, it is obvious that educators must not only ensure learners are educated, but they should be equally motivated and engaged in learning the language.

\section{Speaking Skills}

Since 2017, the Malaysian Instruction Framework has made use of an unused instructional module known as the Popular European Framework of Reference (CEFR). Kathirvel \& Hashim (2020) stated that unlike older programs, teachers have placed a greater proportion of their speaking ability to test through daily training and learning sessions. Additionally, the researchers (Kathirvel \& Hashim, 2020) reported that speaking is a critical ability that language learners must acquire and is critical for communication.

Without it, it is exceedingly difficult to exist in a society that is progressing at a breakneck pace and where English is deemed the primary language of communication. As a result of advances in advanced technologies such as artificial intelligence and virtual reality, there is a growing interest in improving student speech performance (Zhang, et al., 2020). Additionally, Kessler (2018) indicated that speaking has been the least investigated important language ability in comparison to writing, listening and reading. One of the explanations for this lack of research is that it is not a key component of many countries' high school assessment systems, so it is not getting the same level of attention as the aptitude of other dialects (Dark \& William, 2018).

Nonetheless, Wu \& Miller (2020) argued that the ability to speak English is becoming more important to consumers of English as a Second Language (ESL). Technically, the researchers have been able to use English effectively to present their findings at worldwide symposiums. Technically, the use of Business English as a common language. Culturally, social media is expanding across borders, and multiple platforms which offer multi-modal communication options for ESL speakers.

\section{Research Methodology \\ Research Design}

This research used a quantitative approach, which involved a sample questionnaire. A mixed-method analysis is a type of study that begins with the collection of numerical data, analyzes it statistically, and then elaborates on the qualitative findings. A questionnaire containing statements about speaking-based strategies for language learning. Rebecca Oxford's Strategy Inventory for Language Learning (SILL) (1990) served as the basis for the questionnaires. These questionnaires are built in Google Forms and circulated via WhatsApp to students.

\section{Research Participants}

This research was carried out in a Chinese Independent Secondary School in Klang, Selangor. The participants of this research involved a total of 50 Senior 2 Learners. Purposive sampling method was utilized in this research to select the learners. These learners were from diverse classes and have distinctive levels of capability in English. 


\section{Research Instruments}

The data collection instrument for this research was a set of online questionnaires adapted from Rebecca Oxford's Strategy Inventory for Language Learning (SILL) (1990). Thirty elements compose this sample questionnaire, which uses a four-point Likert scale. The fourpoint Likert scale includes (1) Strongly Agree, (2) Agree, (3) Disagree, and (4) Strongly Disagree alternatives that center on the construct "students' preferred English language learning strategies." The thirty elements are classified into six categories such as memory strategies, cognitive strategies, compensatory strategies, metacognitive strategies, affective strategies, and social strategies with an emphasis on speaking ability. Prior to distribution, the researcher handed the questionnaire to some seasoned English lecturers to ensure its face and content legitimacy.

\section{Data Collection}

Data was collected to explore the favored techniques utilized by the learners in upgrading their speaking skill. A link to an online survey questionnaire was disseminated to all the participants.

\section{Data Analysis}

The information from SILL for this research was examined to get the rates and recurrence. The data analysis for the rates and recurrence tallies was conducted utilizing clear measurable analysis.

\section{Findings \& Discussion}

Research Question 1: To find out the learning strategies used by the Senior 2 ESL students of a Chinese Secondary school in improving speaking skills.

\begin{tabular}{|c|l|c|c|c|c|}
\hline NO. & \multicolumn{1}{|c|}{ QUESTIONS } & $\begin{array}{c}\text { STRONGLY } \\
\text { DISAGREE } \\
\text { (n \%) }\end{array}$ & $\begin{array}{c}\text { DISAGREE } \\
\text { (n \%) }\end{array}$ & $\begin{array}{c}\text { AGREE } \\
\text { (n \%) }\end{array}$ & $\begin{array}{c}\text { STRONGLY } \\
\text { AGREE } \\
\text { (n \%) }\end{array}$ \\
\hline $\mathbf{1 .}$ & $\begin{array}{l}\text { Inotice my English } \\
\text { mistakes and use that } \\
\text { information to help me } \\
\text { better. }\end{array}$ & 0 & 7 & $\mathbf{2 9}$ & 14 \\
\hline $\mathbf{2 .}$ & $\begin{array}{l}\text { I pay attention when } \\
\text { someone is speaking } \\
\text { English. }\end{array}$ & 0 & 2 & $\mathbf{2 7}$ & 21 \\
\hline $\mathbf{3 .}$ & $\begin{array}{l}\text { I planmy schedule so I } \\
\text { will have enough time to } \\
\text { study English. }\end{array}$ & 4 & 16 & $\mathbf{2 5}$ & 5 \\
\hline $\mathbf{4 .}$ & $\begin{array}{l}\text { Ilook for people I can talk } \\
\text { to in English. }\end{array}$ & 0 & 12 & $\mathbf{2 6}$ & 12 \\
\hline $\mathbf{5 .}$ & $\begin{array}{l}\text { Ilook for opportunities to } \\
\text { speak as much as possible } \\
\text { in English. }\end{array}$ & 1 & 8 & $\mathbf{3 0}$ & 11 \\
\hline
\end{tabular}

Table 1. Metacognitive Strategy 


\begin{tabular}{|c|c|c|c|c|c|}
\hline No. & QUESTIONS & $\begin{array}{l}\text { STRONGLY } \\
\text { DISAGREE } \\
(\mathbf{n} \%)\end{array}$ & $\begin{array}{l}\text { DISAGREE } \\
(\text { n } \%)\end{array}$ & $\begin{array}{l}\text { AGREE } \\
(\mathbf{n} \%)\end{array}$ & $\begin{array}{l}\text { STRONGLY } \\
\text { AGREE } \\
(\mathbf{n} \%)\end{array}$ \\
\hline 1. & $\begin{array}{l}\text { I think about my progress } \\
\text { in leaming English. }\end{array}$ & 0 & 11 & 32 & 7 \\
\hline 2. & $\begin{array}{l}\text { I try to relax whenever I } \\
\text { feel a fraid of using } \\
\text { English. }\end{array}$ & 3 & 15 & 23 & 9 \\
\hline 3. & $\begin{array}{l}\text { I give myself a reward or } \\
\text { treat when I do well in } \\
\text { English. }\end{array}$ & 8 & 20 & 12 & 10 \\
\hline 4. & $\begin{array}{l}\text { I encourage myself to } \\
\text { speak English even when I } \\
\text { am a fraid of making a } \\
\text { mistake. }\end{array}$ & 0 & 8 & 25 & 17 \\
\hline 5. & $\begin{array}{l}\text { I notice if I am tense or } \\
\text { nervous when I am } \\
\text { studying or using English. }\end{array}$ & 9 & 23 & 15 & 3 \\
\hline
\end{tabular}

Table 2. Affective Strategy

Metacognitive, Affective, Social, Memory, Cognitive and Compensation Strategies which are shown in Table 1 were used by ESL students of a Chinese Secondary school in improving their speaking skills. Among all of the strategies above, indirect strategy which consists of metacognitive strategy is used the most by the students in improving their speaking skills where else for affective strategy, the percentage for agree and disagree is equal.

For metacognitive strategy, in Table 1, $29 \%$ of the students agree that they often attempted to develop their speaking skills by highlighting their mistakes and trying to improve it in their future. Besides that, $27 \%$ of the students agreed that they are always alert and pay attention to someone who can converse well in English as it motivates them to be better at speaking English. $0 \%$ of the students seem to strongly disagree with the above statement .25 $\%$ of the students agreed that they organized their schedule so they will have sufficient time to study English and $26 \%$ of the students stated that they tend to look for people who can communicate with them in English. $11 \%$ of the students strongly felt that they try their best to search for chances to communicate in English whereas $8 \%$ of the students disagree with this statement. In metacognitive strategy, the number of students who agree with all the aspects is the highest compared to the other percentages.

For Table 2 which is Affective Strategy, 32\% of the students always monitor their improvement in learning English and $23 \%$ of them try to calm themselves whenever they feel fearful of using English during a conversation. $20 \%$ of the students disagree that they reward or treat is given to them when they perform well in English. $25 \%$ of the students encourage themselves to be brave even though they make mistakes when speaking in English. However, only $23 \%$ of the students disagree that they tend to observe specifically if they are feeling anxious or nervous when they study or converse in English and finally $26 \%$ of the students disagree that they converse to another individual about their feelings when they communicate in English. 
In conclusion, after analyzing the data, it was apparent that the Senior 2 ESL students of the Chinese Secondary school tend to have their own liking on a specific strategy from the six categories listed by Oxford (1990). The Senior 2 students tend to highlight their mistakes and try to improve it in their future, always alert and pay attention to someone who can converse well in English, organized their schedule so they will have sufficient time to study English, and look for opportunities to read English materials for the metacognitive strategy and try their best to search for chances to communicate in English For, affective strategies it reveals that the Senior 2 students prefer to calm themselves whenever they feel fearful of using English during a conversation, encourage themselves to be brave even though they make mistakes when speaking in English, tend to observe specifically if they are feeling anxious or nervous when they study or converse in English and they converse to another individual about their feelings when they communicate in English. According to Rubaai et al (2019), these findings will help the English language lecturers to plan in terms of selecting learning materials, implementing oral activities, and learning tasks.

Research Question 2: To discover the direct or indirect strategies used by the Senior 2 ESL students of a Chinese Secondary school in improving speaking skills.

\begin{tabular}{|c|c|c|c|c|c|}
\hline \multicolumn{2}{|c|}{ Memory strategy } & \multicolumn{2}{|c|}{ Cognitive strategy } & \multicolumn{2}{|c|}{ Compensation strategy } \\
\hline Question & $\begin{array}{l}\text { Agree } \\
\text { (n \%) }\end{array}$ & Question & $\begin{array}{l}\text { Agree } \\
\text { (n \%) }\end{array}$ & Question & $\begin{array}{l}\text { Agree } \\
\text { (n \%) }\end{array}$ \\
\hline $\begin{array}{l}\text { 1. I think of the } \\
\text { relationship } \\
\text { between what I } \\
\text { already know and } \\
\text { new things Ileam } \\
\text { in English. }\end{array}$ & $\begin{array}{l}72 \% \\
(36)\end{array}$ & $\begin{array}{l}\text { 1. Imake summaries of } \\
\text { information that I hear } \\
\text { in English. }\end{array}$ & $\begin{array}{l}28 \% \\
(14)\end{array}$ & $\begin{array}{l}\text { 1. To understand } \\
\text { unfamiliar English } \\
\text { words, I make guesses. }\end{array}$ & $\begin{array}{l}64 \% \\
(32)\end{array}$ \\
\hline $\begin{array}{l}\text { 2. I use new } \\
\text { English words in a } \\
\text { sentence so I can } \\
\text { remember them. }\end{array}$ & $\begin{array}{l}50 \% \\
(25)\end{array}$ & $\begin{array}{l}\text { 2. I try to find patterns } \\
\text { in my conversation } \\
\text { when I speak in English }\end{array}$ & $\begin{array}{l}46 \% \\
(23)\end{array}$ & $\begin{array}{l}\text { 2. When I can't think of } \\
\text { a word during a } \\
\text { conversation in English, } \\
\text { I use gestures. }\end{array}$ & $\begin{array}{l}58 \% \\
(29)\end{array}$ \\
\hline $\begin{array}{l}\text { 3. I use rhymes to } \\
\text { remembernew } \\
\text { English words. }\end{array}$ & $\begin{array}{l}24 \% \\
(12)\end{array}$ & $\begin{array}{l}\text { 3. I find the meaning of } \\
\text { an English word by } \\
\text { dividing it into parts } \\
\text { that I understand. }\end{array}$ & $\begin{array}{l}46 \% \\
(23)\end{array}$ & $\begin{array}{l}\text { 3. I make up new words } \\
\text { if I do not know the right } \\
\text { ones in English. }\end{array}$ & $\begin{array}{l}36 \% \\
(18)\end{array}$ \\
\hline $\begin{array}{l}\text { 4. I use flashcards } \\
\text { to remember new } \\
\text { English words. }\end{array}$ & $\begin{array}{c}16 \% \\
(8)\end{array}$ & $\begin{array}{l}\text { 4. I prepare notes and } \\
\text { presentations in } \\
\text { English. }\end{array}$ & $\begin{array}{l}42 \% \\
(21)\end{array}$ & $\begin{array}{l}\text { 4. I try to guess what the } \\
\text { other person will say } \\
\text { next in English. }\end{array}$ & $\begin{array}{l}54 \% \\
(27)\end{array}$ \\
\hline $\begin{array}{l}\text { 5. I say or write } \\
\text { new English words } \\
\text { several times. }\end{array}$ & $\begin{array}{l}62 \% \\
(31)\end{array}$ & $\begin{array}{l}\text { 5. I try not to translate } \\
\text { word-for-word. }\end{array}$ & $\begin{array}{l}50 \% \\
(25)\end{array}$ & $\begin{array}{l}\text { 5. I can't think of an } \\
\text { English word, I use a } \\
\text { word or phrase that } \\
\text { means the same thing. }\end{array}$ & $\begin{array}{l}52 \% \\
(26)\end{array}$ \\
\hline
\end{tabular}

Table 3. Direct strategies

A total of two tables have been presented to analyze the findings in discovering the direct or indirect strategies used by ESL students of a Chinese Secondary school in improving speaking skills. Table 3 as shown above presents the results of the direct strategies that were used by students in developing their speaking skills in the English language. Among all of the direct strategies above, memory strategy was revealed to have the highest percentage which is $72 \%$, then compensation strategy with $64 \%$, and cognitive strategy with $50 \%$. A total of 36 
out of 50 students, of which $72 \%$ have chosen, agreed that they always relate their understanding with their past knowledge about how to speak well in English while only $62 \%$ which is only 31 students preferred to use the method of saying and writing the English words repeatedly as it could develop their speaking skill. Besides that, only $50 \%$, which is 25 out of 50 students have attempted to use some new English words in a sentence as it allows them to remember the words well. Aside from that, compensation strategy has become the second commonly used direct strategy by students in improving their speaking skills. The percentage was $64 \%$ which is 32 out of 50 students have tried to make some assumptions to guess the unknown English words, while $58 \%$ which is 29 out of 50 students have even tried to use gestures when they are incapable to think of the proper words to use during a conversation in English. In addition to that, 54\% of the students, which is 27 of the students sometimes, have tried to make some guesses of what the other person will say next in English. Finally, the highest percentage obtained from the questionnaire was $50 \%$ which is a total of 25 students who had tried to not interpreting every word, and $46 \%$ which is 23 out of 50 students attempted to identify the same pattern as they speak the language as well as discovering the meaning of the words by dividing it into several parts that they understand to improve their speaking skill in English.

\begin{tabular}{|c|c|c|c|c|c|}
\hline \multicolumn{2}{|c|}{ Metacognitive strategy } & \multicolumn{2}{|l|}{ Affective strategy } & \multicolumn{2}{|c|}{ Social strategy } \\
\hline Question & $\begin{array}{l}\text { Agree } \\
(\mathrm{n} \%)\end{array}$ & Question & $\begin{array}{l}\text { Agree } \\
(\mathrm{n} \%)\end{array}$ & Question & $\begin{array}{l}\text { Agree } \\
(n \%)\end{array}$ \\
\hline $\begin{array}{l}\text { 1. I notice my } \\
\text { English mistakes } \\
\text { and use that } \\
\text { information to } \\
\text { help me better. }\end{array}$ & $\begin{array}{l}58 \% \\
(29)\end{array}$ & $\begin{array}{l}\text { 1. I think about my progress } \\
\text { in leaming English }\end{array}$ & $\begin{array}{l}64 \% \\
(32)\end{array}$ & $\begin{array}{l}\text { 1. I try to talk like } \\
\text { native English } \\
\text { speakers. }\end{array}$ & $\begin{array}{l}56 \% \\
(28)\end{array}$ \\
\hline $\begin{array}{l}\text { 2. I pay attention } \\
\text { when someone is } \\
\text { speaking English. }\end{array}$ & $\begin{array}{l}54 \% \\
(27)\end{array}$ & $\begin{array}{l}\text { 2. I try to relax whenever I } \\
\text { feel a fraid of using English }\end{array}$ & $\begin{array}{l}46 \% \\
(23)\end{array}$ & $\begin{array}{l}\text { 2. I start a } \\
\text { conversation in } \\
\text { English. }\end{array}$ & $\begin{array}{l}50 \% \\
(25)\end{array}$ \\
\hline $\begin{array}{l}\text { 3. I plan my } \\
\text { schedule so I will } \\
\text { have enough time } \\
\text { to study English. }\end{array}$ & $\begin{array}{l}50 \% \\
(25)\end{array}$ & $\begin{array}{l}\text { 3. I give myself a reward or } \\
\text { treat when I do well in } \\
\text { English }\end{array}$ & $\begin{array}{l}24 \% \\
(12)\end{array}$ & $\begin{array}{l}\text { 3. I watch English } \\
\text { language TV shows } \\
\text { spoken in English or } \\
\text { go to movies spoken } \\
\text { in English. }\end{array}$ & $\begin{array}{l}34 \% \\
(17)\end{array}$ \\
\hline $\begin{array}{l}\text { 4. I look for } \\
\text { people I can talk } \\
\text { to in English. }\end{array}$ & $\begin{array}{l}52 \% \\
(26)\end{array}$ & $\begin{array}{l}\text { 4. I encourage myself to } \\
\text { speak English even when I } \\
\text { am afraid of making a } \\
\text { mistake }\end{array}$ & $\begin{array}{l}50 \% \\
(25)\end{array}$ & $\begin{array}{l}\text { 4. I ask English } \\
\text { speakers to correct } \\
\text { me when I talk. }\end{array}$ & $\begin{array}{l}38 \% \\
(19)\end{array}$ \\
\hline \multirow{2}{*}{$\begin{array}{l}\text { 5. I look for } \\
\text { opportunities to } \\
\text { speak as much as } \\
\text { possible in } \\
\text { English. }\end{array}$} & $\begin{array}{l}60 \% \\
(30)\end{array}$ & $\begin{array}{l}\text { 5. I notice if I am tense or } \\
\text { nervous when I am } \\
\text { studying or using English }\end{array}$ & $\begin{array}{l}30 \% \\
(15)\end{array}$ & $\begin{array}{l}\text { 5. I try to leam } \\
\text { about the culture of } \\
\text { English speakers. }\end{array}$ & $\begin{array}{l}48 \% \\
(24)\end{array}$ \\
\hline & & $\begin{array}{l}\text { 6. I talk to someone else } \\
\text { about how I feel when I am } \\
\text { leaming English. }\end{array}$ & $\begin{array}{l}36 \% \\
(18)\end{array}$ & & \\
\hline
\end{tabular}

Table 4. Indirect strategies

Other than direct strategies, some of the students also have chosen indirect strategies that could develop their speaking skills in the English language. Table 4 shown above displays the results of the indirect strategy that students applied in improving their speaking skills. Among all the indirect strategies above, metacognitive strategy has become the most used strategy with the highest percentage which is $60 \%$, then affective strategy with $64 \%$, and 
social strategy with $56 \%$. A total of 30 out of 50 students which $60 \%$ have chosen agreed that they often attempted to use every chance that they had to converse as much as possible in English while only 29 of the students which are $58 \%$ of them always tried to develop their speaking by highlighting their mistakes and tried to improve it in the future. However, only 27 of the $54 \%$ of the students agreed that they are always alert and pay attention to someone who can converse well in English as it encourages them to be better at speaking English. Apart from that, effective strategy has become the second most used strategy by the students in improving speaking skills. With the percentage of $64 \%$, a total of 32 of the students agreed that they always monitor their improvement in learning English while $50 \%$ of them, which is 25 out of 50 of the students encouraged themselves to be brave even though they make mistakes when speaking in English. Furthermore, to improve their speaking skills $46 \%$ of the students, which is 23 out of 50, try to calm themselves whenever they feel afraid of using English during a conversation. Last but not least, the highest percentage obtained from the questionnaire for social strategy is $56 \%$ which is 28 of the students who tried to be more socialized by talking like a native English speaker to others, and $50 \%$ of students which is 25 of them tried to be brave to start the conversation in English. Then, $48 \%$ of the students, which is 24 out of 50 students, choose to agree that learning the culture of English speakers could improve their speaking skills in English.

Apart from that, metacognitive strategy has been seen to be the most used indirect strategy by students in enhancing speaking skills as shown in table 4 . By implementing the metacognitive strategy, students have agreed that this strategy enables them to focus more on their self-improvement towards developing their speaking skills. Based on the data obtained, students agreed that using most of the chances that they have to communicate in English may enhance their speaking skills. This is because students can explore by themselves the better way of speaking when they use the chances they have. Other than that, students also have agreed that being alert and paying attention to someone who can converse well in English inspires them to be more skilled at speaking English as well as allowing them to discover their weaknesses and make some improvement to it

Therefore, it can be concluded that indirect strategies were the most used by ESL students of a Chinese Secondary school in improving speaking skills. This is because most of the students have chosen to agree to all questions that have been stated in the metacognitive strategy section. This can be said that students preferred to use a strategy that allows them to monitor their improvement while learning something during the process of becoming a great speaker in English. As stated previously, this strategy does allow them to control their learning process and become an independent learner. As independent learners, this strategy enables them to plan their learning schedule, fix their mistakes, and explore the opportunities that they have to speak more in the English language. Idris (2019) added that applying indirect strategy as one of the strategies in improving speaking skills may help the students to have an appropriate plan that can develop their difficulty in improving the speaking skill in English. Besides that, Rahimi (2011) has stated that having a vital strategy in learning may bring consciousness to the learners to plan accordingly their learning process in developing their speaking skills. Thus, it will benefit the learners and achieve success when learners are equipped with the knowledge and capability to employ the appropriate strategy in enhancing speaking skills. 


\section{Conclusion}

To conclude, recognizing LLSs appears to be an arrangement for ESL issues. Changing the conventional way of learning isn't a straightforward errand and conducting more investigation may lead to recognizing the assortment of methodologies learners can utilize to memorize successfully. Moreover, modern techniques may be found. Appropriately, dialect classrooms ought to center on teaching and creating learning. The suggestion for instructing is that learners have to explore their LLSs concurring to their targets. In addition, instructors got to investigate what procedures the learners utilize for each objective. Instructors ought to attempt to prepare as independent learners as they can. Independent learners are able to evaluate the common sense of a methodology basically. They can select the suitable methodology for an errand and successfully transfer it to an unused errand.

In brief, this research concluded that the metacognitive approach is the most often utilized LLS among Independent Chinese School students. There is just a small disparity between metacognitive and affective strategies in terms of the outcome. One might argue that the majority of Independent Chinese School ESL students combine these two techniques while learning a second language. On the other hand, the results also depict that most of the students are using the direct strategies more to improve their speaking skills in English compared to using indirect strategies. The details provided in the findings and discussion sections corroborate this.

LLS is a vast space that deserves to be studied. The researchers and study conducted would contribute to the development of a solid foundation that would undoubtedly benefit the education field. Regardless of the results, they are indeed learners who fail to understand and develop. Occasionally, learners are mindful of the presence of LLSs and are motivated to help the whole learning phase, but the result does not fit the desired outcome. This is why researchers can continue to investigate, because not all findings should be applied to all types of learners. Though assumptions may be made, testing must be conducted to demonstrate its efficacy.

\section{References}

Adan, D. and Hashim, H. (2021). Language Learning Strategies Used by Art School ESL Learners. Creative Education, 12, 653-665. doi: 10.4236/ce.2021.123045.

Ali, A., Zaman, A., \& Khan, F. A. (2018). Language Learning Strategy Use and English Language Proficiency. Global Social Sciences Review, 3(2), 439-453.

Bayuong, P. D., Hashim, H., \& Yunos, M. M. (2019). Identifying Language Learning Strategies Used by ESL Learners in a Rural Primary School. International Journal of Academic Research in Progressive Education \& development, 4, 151-165. https://doi.org/10.6007/IJARPED/v8-i3/6311

Black, P., Wiliam, D. (2018). Classroom assessment and pedagogy. Assessment in Education: Principles, Policy \& Practice 25(6): 551-75.

Boonkit, K. (2010). Enhancing the development of speaking skills for non-native speakers of English. Procedia-social and behavioral sciences, 2(2), 1305-1309.

Lee, C. K. (2010). An Overview of Language Learning Strategies. Annual Review of Education, Communication, and Language Sciences, 7.

Cohen, A. D., Oxford, R. L., \& Chi, J. C. (2005). Learning style survey for young learners:

Assessing your own learning styles.

Fromkin, V., Rodman, R., \& Hyams, N. (2018). An introduction to language. Cengage Learning. 
Gani, S. A., Fajrina, D., \& Hanifa, R. (2015). Students' learning strategies for developing speaking ability. Studies in English Language and Education, 2(1), 16-28.

Hardan, A. A. (2013). Language learning strategies: A general overview. Procedia-Social and Behavioral Sciences, 106, 1712-1726.

Hashim, H. U., Yunus, M. M., \& Hashim, H. (2018). Language Learning Strategies Used by Adult Learners of Teaching English as a Second Language (TESL). TESOL International Journal, 13(4), 39-48

Heriansyah, H. (2012). Speaking problems faced by the English Department students of Syiah Kuala University. Lingua Didaktika: Jurnal Bahasa dan Pembelajaran Bahasa, 6(1), 3744.

Kashefian-Naeeini, S., \& Maarof, N. (2010). Language Learning Strategies used by ESL University Students. International Journal of Learning, 17(8).

Kathirvel, K., \& Hashim, H. (2020). The Use of Audio-Visual Materials as Strategies to Enhance Speaking Skills among ESL Young Learners. Creative Education, 11(12), 2599-2608.

Kessler, G. (2018) Technology and the future of language teaching. Foreign Language Annals 51(1): 205-18.

Nisbet, J., \& Shucksmith, J. (2017). Learning strategies. Routledge.

Oxford, R. (1990). Language learning strategies. New York, 3.

Oxford, R. L. (Ed.). (1996). Language learning strategies around the world: Cross-cultural perspectives (No. 13). Natl Foreign Lg Resource Ctr.

Pawlak, M. (2019). Investigating language learning strategies: Prospects, pitfalls and challenges. Language Teaching Research, 1362168819876156.

Rubaai, N., Hashim, H., \& Yunus, M. M. (2019). Identifying English Language Learning Strategies Used by Polytechnic Students. Religación, 4, 98-103.

Shi, H. (2017). Learning strategies and classification in education. Institute for Learning Styles Journal, 1(1), 24-36.

Sykes, A. H. (2015). The good language learner revisited: A case study. Journal of Language Teaching and Research, 6(4), 713.

Thirusanku, J., \& Yunus, M. M. (2014). Status of English in Malaysia. Asian Social Science, 10(14), 254.

Winarsih, R., Salam, U., \& Riyanti, D. (2021). AN ANALYSIS OF STUDENTS' LANGUAGE LEARNING STRATEGIES IN ACADEMIC WRITING. Jurnal JOEPALLT (Journal of English Pedagogy, Linguistics, Literature, and Teaching), 9(1).

Wu, J. G., \& Miller, L. (2020). Improving English learners' speaking through mobile-assisted peer feedback. RELC journal, 51(1), 168-178.

Zaw, E. M. (2019). Creating Positive English Language Learning Environment through Communicative Language Teaching. 2nd International Conference on Engineering Education and Innovation.

Zhang, D., Wang, M., \& Wu, J. G. (2020). Design and implementation of augmented reality for English language education. In Augmented Reality in Education (pp. 217-234). Springer, Cham. 